\title{
ДОСВІД ВИКОРИСТАННЯ ТЕХНОЛОГІЙ ДИСТАНЦІЙНОГО НАВЧАННЯ У ПРОЦЕСІ ПІДГОТОВКИ МАЙБУТНІХ ФАХІВЦІВ МЕДИЧНОЇ ГАЛУЗІ
}

\author{
С. О. Дуднік, Н. В. Телефус \\ Комунальний заклад «Ніжинський фаховий медичний коледж» \\ Чернігівської обласної ради
}

\begin{abstract}
У статті висвітлено форми і методи дистанційної підготовки майбутніх медичних сестер.
\section{EXPERIENCE IN USING TECHNOLOGIES OF EXTRAMURAL EDUCATION IN THE STUDYING PROCESS OF FUTURE MEDICAL WORKERS}

\author{
S. O. Dudnik, N. V. Telefus \\ Municipal Institution “Nizhyn Professional Medical College” of Chernihiv Regional Council
}

The article highlights the forms and methods of extramural education of future nurses.

Вступ. Зміни, що торкнулися освітнього процесу в державі у зв'язку з початком пандемії COVID-19, зачепили і нашу фахову передвищу медичну освіту.

Колективу нашого закладу довелось швидкими темпами освоювати різні форми дистанційного навчання. Для цього були створені курси для викладачів у літній період часу, заняття на засіданнях школи педагогічної майстерності, школи молодого викладача, засідання циклових комісій.

Дистанційне навчання було розпочате у березні на веб-сервісі Google Клас, а далі і Zoom, Meet та ін.

Звичайно краще справляються викладачі з теоретичними заняттями, адже у кожного є накопичений матеріал лекцій - це відеофільми, презентації, що дозволяють якісно проводити теоретичні заняття.

Складніше питання постало перед викладачами при проведенні практичних занять, особливо з клінічних дисциплін. Адже навчити медика дистанційно маніпуляціям та наданню допомоги при невідкладних станах вкрай складно. Тому дотримуючись усіх правил безпеки частину занять намагаємося проводити в тренажерних кабінетах, а частину дистанційно.

Як же навчити майбутню медичну сестру дистанційно засвоїти свої професійні вміння та навички? Які проблеми виникають? Які особливості проведення занять? Як поєднується теорія з практикою дистанцій-

(с) С. О. Дуднік, Н. В. Телефус, 2021 но? Які форми і методи найдієвіші? Ці та безліч інших питань постійно постають перед колективом викладачів. І на них ми шукаємо все нові й нові відповіді.

Колективом проаналізовано засоби, методи, форми та платформи для дистанційного навчання, які використовують у навчальних закладах України [1, 2]. Проведено ряд навчань, майстер-класів, конференцій, де були успішно апробовані ці засоби.

Основна частина. Сьогодні хочемо поділитися 3 вами досвідом проведення дистанційних занять зі спеціалізації «Сестринська справа» на прикладі дисципліни «Основи медсестринства».

На початковому етапі практичного заняття, для перевірки початкового рівня знань студентів, використовуємо традиційно тестовий контроль, але не на паперових носіях, а на веб-сервісі Google Клас. Тестові завдання різного типу створюють за допомогою Google Форми. Типи тестових завдань різні: конкретні запитання, що передбачають коротку відповідь, на одиничний чи множинний вибір або на знаходження відповідностей [3]. Посилання на тести розміщується в завданні до теми практичного заняття. Усне фронтальне опитування проводимо спілкуючись у додатку Meet, це зручно, бо для цього достатньо мати смартфон, щоб працювати на занятті.

Основний етап практичного заняття передбачає опанування студентами практичних вмінь з дис- 
ципліни в кабінетах доклінічної практики. Як вдало дистанційно організувати цей етап? Чи існують труднощі? які саме?

Аналізуючи роботу за період карантину потрібно зазначити, що основна проблема - це відсутність вдома у студентів фантомів, муляжів та необхідного оснащення, якому важко знайти альтернативу.

Інша проблема - це відсутність статиста, який перебуває поряд зі студентом і працює з ним у парі, в ролі пацієнта, під час заняття для набуття навичок спілкування, догляду за пацієнтами та медичної маніпуляційної техніки.

Для вирішення цих проблем проаналізовано практичні навички з дисципліни «Основи медсестринства» і умовно поділено на такі групи:

- заповнення медичної документації;

- навчання пацієнтів;

- спостереження та аналіз і оцінювання отриманих даних;

- маніпуляційна техніка;

- розрахункові навички.

Для кожної з них доречно використовувати ті чи інші методи дистанційного навчання.

Вивчаючи тему «Прийом пацієнта», на веб-сервісі Google Клас викладач створює матеріал, в який додає копії облікових форм (медичну карту хворого, журнал обліку осіб, госпіталізованих у стаціонар) з можливістю редагування, для кожного студента. Студенти по можливості роздруковують паперовий примірник до початку заняття або працюють у форматі Word, завантаживши ці документи на персональний комп'ютер. Відеоалгоритми заповнення цих документів створені з використанням розширення браузера Screencastify [3]. Студенти можуть переглядати відео та одночасно заповнювати ці документи.

Для опанування навичок навчання пацієнтів особливостей дотримання лікувальної дієти чи підготовки до додаткових досліджень кожний студент отримує окреме завдання та план відповіді. За визначений викладачем час (5 хв) студент готує тези бесіди з пацієнтом. Далі, працюючи в додатку Meet, він розповідає студентам бригади про особливості підготовки, студенти можуть ставити уточнювальні запитання та оцінювати один одного, а викладач коригувати та оцінювати рівень навичок.

Якщо на основний етап заняття винесені навички спостереження, оцінювання та реєстрації отриманих результатів термометрії, частоти дихання, пульсу, артеріального тиску, то студенти переходять за поси- ланням, яке розміщене в темі заняття на веб-сервісі Google Клас, спочатку переглядають відеоалгоритм навичок, обговорюють з викладачем побачене, акцентують увагу на важливих моментах. Потім, за даними клінічного завдання, яке через демонстрацію екрана в Meеt виводиться на слайд викладачем, студенти оцінюють стан пацієнта за його життєво важливими показниками та реєструють результати до температурного листка. Відпрацювання цих навичок студенти проводять у родинному колі з відеофіксацією виконаного, яку прикріплюють до завдання та надсилають викладачу на перегляд та оцінювання.

Для опанування навичок виконання ін'єкцій викладач надсилає заздалегідь перелік оснащення, що знадобиться для роботи (шприци, ампули, флакони, спиртові серветки тощо). У процесі заняття в додатку Meet викладач демонструє, а студенти повторюють за ним виконання маніпуляції.

Розрахункові навички (приготування дезрозчинів певної концентрації, розрахунок дози інсуліну для введення, розрахунок дози антибіотиків для введення тощо) студенти опановують переглядаючи відеоалгоритм, де ці розрахунки проводить викладач. Подібні розрахункові завдання за кількістю студентів бригади готує викладач заздалегідь в додатку Jamboard [3] та надає доступ кожному для роботи на занятті. Потім один зі студентів виконує обчислення, а інші студенти бригади спостерігають за його роботою та вправляються в проведенні розрахунків у щоденниках для практичних занять.

Підсумковий етап практичного заняття передбачає контроль та корекцію рівня опанованих фахових вмінь. На цьому етапі кожен студент отримує окреме нетипове клінічне завдання у веб-сервісі Google Клас, яке самостійно письмово виконує у щоденнику та презентує відповідь в додатку Meet. Також проводимо роботу малими групами. Наприклад, заповнення графологічної схеми, запропонованої викладачем, складання плану сестринських втручань для вирішення певної проблеми пацієнта. І хоча викладачу складно оцінювати внесок кожного студента у роботу, яку презентує представник групи, проте формується компетенція командної роботи, яка $\epsilon$ важливою у роботі медичної сестри.

Програмою з дисципліни «Основи медсестринства» передбачена самостійна позааудиторна робота, яка була спланована, розроблено методичні вказівки до виконання. Кожний студент виконує різноманітні форми самостійної позааудиторної роботи в уніфікованих 
зошитах із друкованою основою. Найбільш вдалими формами виконання самостійної роботи є відпрацювання медичних маніпуляцій в тренажерному кабінеті коледжу з відеофіксацією, яку надають студенти для оцінювання викладачу.

Під час вивчення теми «Медсестринський процес» використовували самостійну роботу студентів із перегляду різних сюжетів телепроекту «Я соромлюсь свого тіла». Студенти обирали певний сюжет проекту, аналізували стан пацієнта, виявляли його проблеми, проводили сестринську діагностику, визначали мету та планували сестринські втручання. Презентацію самостійної роботи проводили на практичному занятті в додатку Meеt. Заповнену сестринську історію пацієнта студенти надсилали окремим файлом викладачу для перевірки.

\section{СПИСОК ЛІТЕРАТУРИ}

1. Бурико О. М. Нові часи - нові можливості, або навчання в смартфоні / О. М. Бурико // Медсестринство. 2020. - № 1. - С. 42-43.

2. Досвід проведення дистанційних онлайн-семінарів під час карантину на кафедрі хірургії № 1 з урологією, малоінвазивною хірургією та нейрохірургією імені Л. Я. Ко-
Висновки. Дистанційні форми навчання у підготовці майбутньої медичної сестри однозначно виправдовують себе під час проведення теоретичних занять та засвоєння теоретичних навичок і вмінь. Проте опанувати навички і вміння, які пов'язані з маніпуляційною технікою вкрай складно для студентів. Результати роботи показують, що навіть якщо студент теоретично засвоїв алгоритм виконання практичної навички, це не означає, що він може ії виконати практично на фантомі. Для майбутнього медичного фахівця просто необхідний постійний практичний тренінг у кабінетах доклінічної практики та тренажерних кабінетах під контролем викладача, бо лише так вони зможуть засвоїти їх до автоматизму.

вальчука / А. Д. Беденюк, С. Й. Гриценко, В. Б. Доброродній, А. Є. Бурак // Медична освіта. - 2020. - № 3. - С. 21-23.

3. Розгортання та використання середовища G Suite в діяльності освітньої установи педагога [Електронний ресурс]. - Режим доступу : https://cutt.ly/5hWtDrz. 